高位腹部大動脈閉塞症の手術と問題点

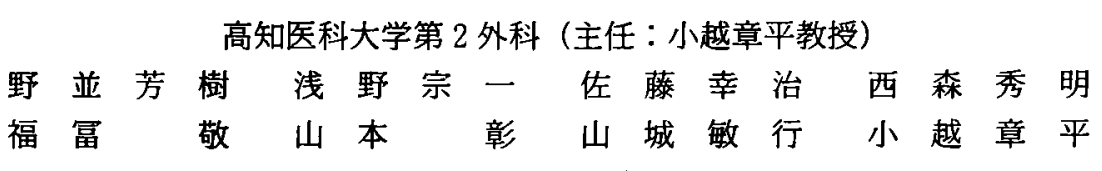

過去14年間に高位腹部大動脈閉塞症の10例を経験し急性例 1 例を含む 5 例に anatomical bypass 術を，急性例 1 例を含む 5 例に extra-anatomical bypass 術を施行した。急 性 2 例は myonephropathic metabolic syndrome 発症のため救命出来なかった。待機手 術例の術前からの嗜好・手術前淢器機能低下, 術前後の腎機能の推移, 手術法, 手術後 合併症，予後，併せて重篤な病態である急性 2 例の臨床像を提示し，その問題点を検討 した.

索引用語：高位腹部大動脈閉塞症, high aortic occlusion, anatomical bypass, extraanatomical bypass

\section{緒言}

本邦においても高龄化，食生活の欧米化とともに閉 塞性動脈硬化症の発生頻度は高くなっており, いわゆ る Leriche syndrome を呈する症例も増加している。 Leriche syndrome が進行した状態である高位腹部大 動脈閉塞症 (high aortic occlusion) は下肢, 惄部の 虚血症状のみでなく督蔵をはじめ, 内蔵臓器への血行 阻害をきたす恐れのある重篤な病態である。急性例 2 例を含む10例の自験例を中心に，その病態，手術法， 予後について検討したので報告する。

\section{症例および方法}

昭和57年 4 月から平成 7 年 3 月までの 14 年間に手術 施行した Leriche syndrome 23例のうち高位腹部大動 脈閉塞症は男性 9 例女性 1 例の10例であった. 術式別 では anatomical bypass (以下 ANA, 平均年龄56歳) 手術例, extra-anatomical bypass（以下EXT, 同77 歳) 手術例ともに 5 例であり各々急性例を 1 例含んで いた. 手術前嗜好・手術前臓器機能低下, 手術前後の 腎機能の推移, 手術前後の ANA 群 6 肢, EXT 群 6 肢 ての安静時総大眼動脈 pulsatility index (以下PI 值 $)=0.6 \times($ 最大流速一最小流速 $) /$ 平均流速, mean blood flow (以下 MBF 值) =面積 $\times$ 平均流速の推移, 手術後合併症および問題点の多い急性高位腹部大動脈 閉塞 2 症例を提示する.

\section{結 果}

1) 手術前㖺好·手術前轖器機能低下：両群ともに急 性例を除く各 4 例計 8 例で検討した。全例，喫煙歴が あり Brickman 指数 1,000 以上は 7 例（86\%）に500以 上は全例に認めた。 EXT群では 2 例に陳旧性心筋梗 塞, 狭心症の既往があり, 他の主たる risk factor は腎 機能障害, 腹部大動脈石灰化, 80 歳以上の高年齢であっ た(表 1 ).

2）腎機能の推移：ANA 群では全例腎動脈分岐部 より中枢側大動脈遮断を行い遮断時間は最長25分平均 10分であった。大動脈遮断を要しないEXT群と比べ て術翌日のクレアチニンの軽度高値を認めたが有意差 はなく, BUN 值も両群間に差異を認めなかった（図 $1)$.

3）MBF 值, PI 值の術前後の推移： duplex colour doppler を用いて検索した. MBF 值は著変を認めず, PI 值は両群とも手術後, 上昇し $2.15 \pm 0.38,2.21 \pm$ 0.45 と両群間で差異はなかった（図 2 ）。

4) 術後合併症：慢性例では ANA 群で 1 例に遠隔 期 Y グラフト左脚の閉塞を認め, EXT 群でも術直後 2 例に胃出血, 遠隔期グラフト閉塞を 1 例に認めた。 急性例 2 例は myonephropathic metabolic syndrome （以下 MNMS）をきたし救命出来なかった（表 2 ）. 次に急性高位閉塞症の 2 例を提示する。

（症例 $1 ） 68$ 歳, 男性, 突然の発症から約30時間後, 緊急入院したが, 極度の呼吸困難, 代謝性アシドーシ 
表 1 啫好・術前機能低下

* 待機手街例

\begin{tabular}{|c|c|c|}
\hline Risk Factor & $\begin{array}{c}\text { Anatomic Bypass } \\
\text { 4别" }\end{array}$ & $\begin{array}{c}\text { Extra-anatomic Bypass } \\
401\end{array}$ \\
\hline 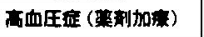 & $1(25 \%)$ & $2(50 \%)$ \\
\hline 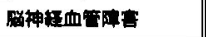 & $1(25 \%)$ & $1(25 \%)$ \\
\hline $\begin{array}{l}\text { 冠功脈英甞 } \\
\text { (OMI, Angina) }\end{array}$ & $1(25 \%)$ & $2(50 \%)$ \\
\hline 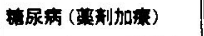 & 0 & 0 \\
\hline 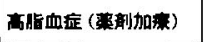 & $1(25 \%)$ & $3(75 \%)$ \\
\hline 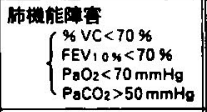 & $1(25 \%)$ & $2(50 \%)$ \\
\hline 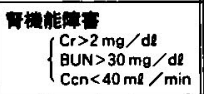 & 0 & $1(25 \%)$ \\
\hline 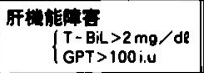 & 0 & 0 \\
\hline 的的街既往 & $1(25 \%)$ & 0 \\
\hline 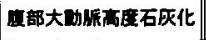 & 0 & $1(25 \%)$ \\
\hline 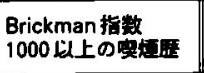 & 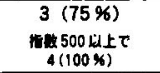 & $4(100 \%)$ \\
\hline 80 以上 & 0 & $1(25 \%)$ \\
\hline
\end{tabular}
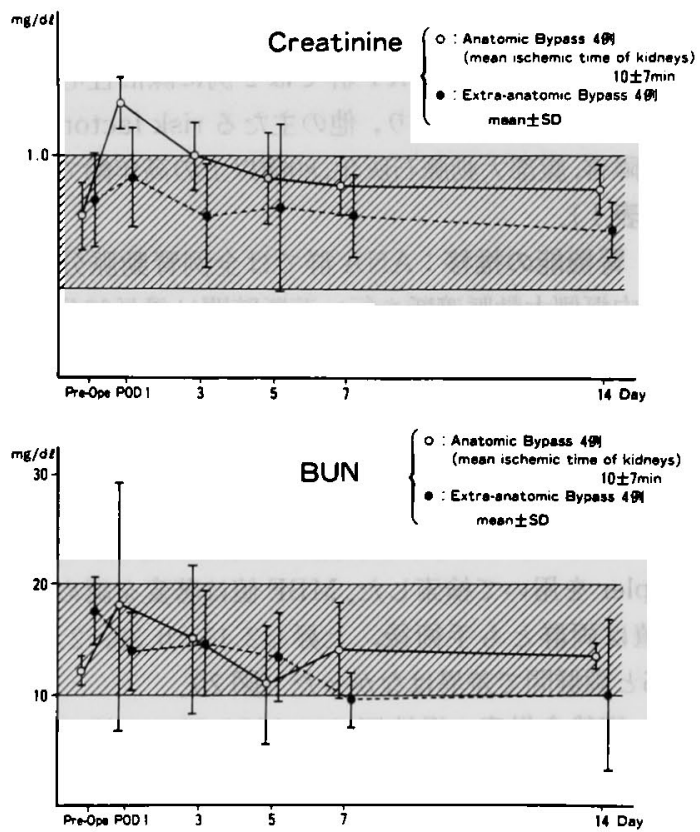

図 1 塥機能の推移

スを呈しており腹部単純写真で腸の広範なガス拡張 像, DSA 像での腹部大動脈高位閉塞, 血液検查で筋代 謝産物の著明な上昇を認めた。極めて重篤な状態で
表 2 術後合併症

\begin{tabular}{|c|c|c|c|c|c|}
\hline 症到 & 性别 & 年野 & 街荲饶合拼症 & 通凮期合併应 & 完重 \\
\hline \multicolumn{6}{|c|}{$\mathrm{Y}$-Grafting } \\
\hline$T . Y$. & 男 & 47 & $(-)$ & $(-)$ & 在 \\
\hline E.F. & 男 & 67 & $(-)$ & 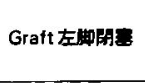 & $\begin{array}{c}\text { Lt. Axillo-Femoro } \\
\text {-Popliteal Bypass } \\
\text { rel }\end{array}$ \\
\hline o.s. & 男 & 64 & \begin{tabular}{|l|} 
左大心期 \\
リンバ
\end{tabular} & $(-)$ & 请在 \\
\hline M.Y. & 男 & 67 & $(-)$ & $(-)$ & 在 \\
\hline$T . M * *$ & 男 & 68 & \multicolumn{3}{|c|}{ 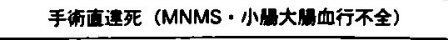 } \\
\hline
\end{tabular}

\begin{tabular}{|c|c|c|c|c|c|}
\hline Y.N. & 男 & 83 & 出出血 & 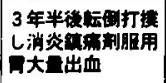 & $\begin{array}{c}\text { 3年半摞 } \\
\text { 死亡 }\end{array}$ \\
\hline Y.T. & 男 & 64 & $(-)$ & $(-)$ & 在 \\
\hline S.M. & 男 & 68 & $(-)$ & Graft閒害 & $\begin{array}{l}\text { Lt. Axillo-Femoral } \\
\text { Bypass } \\
\text { a在 }\end{array}$ \\
\hline F.o. & 女 & 68 & 田出血 & $(-)$ & 盟在 \\
\hline s. $1^{\circ}$ & 男 & 78 & \multicolumn{3}{|c|}{ (MNMS) } \\
\hline
\end{tabular}

*密性离位閏要例

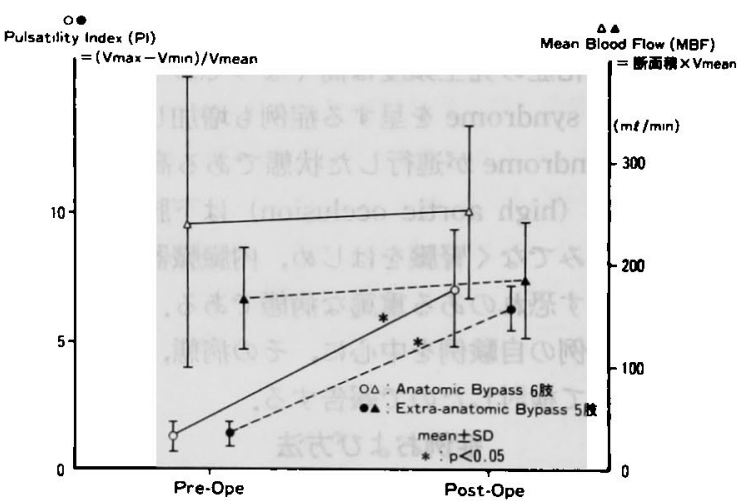

图 $2 \mathrm{MBF}$ 值, PI 值術前後の推移

あったが内蔵蔵器への血行再建あるいは腸切除を要す るために緊急手術を行い下腸間膜動脈，両側腎動脈血 行再開，Y グラフト置換，下腸間膜動脈の血行再建を 行ったが術中, MNMSによる心不全のため失った(図 $3)$.

（症例 2 ）78歳, 男性, 直腸癌のため近医で Milés 手 術を受け, その直後から, 右下肢冷感が出現し, 発症 から20時間後, 緊急入院となった．既往歴に戦傷で左 大腿切断, 㹟心症, 高血圧症を認めていた. 直ちに右 腋窩大腿䅣窩動脈バイパス術を行ったが術直後, ST の著明な低下，心室頻拍を呈したため，膝窝動脈への 血行を遮断した，術翌日，血液検查で筋代謝産物の著 


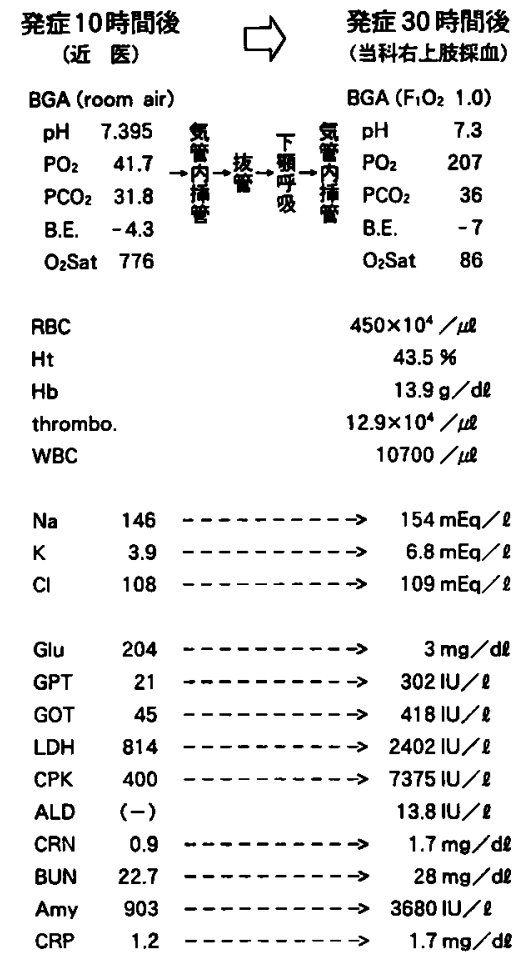

图 3 症例 1

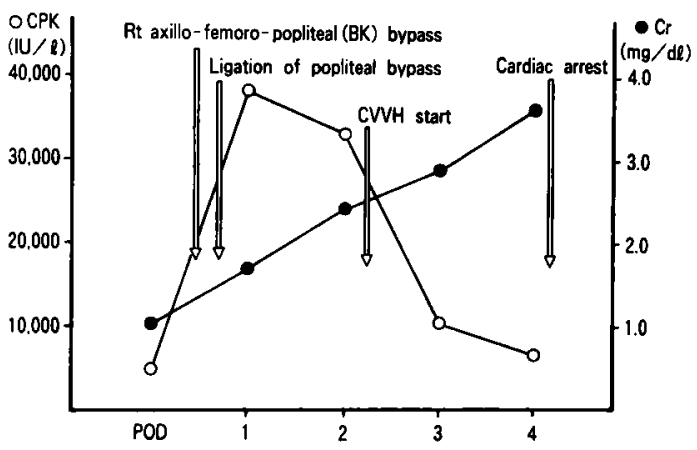

図 4 症例 2

明な上昇を認め，尿量の低下も生じたため continuous veno-venous hemodialysis を行ったが䚘後第 4 病日, MNMS のため失った（図4).

\section{考 察}

高位腹部大動脈閉塞症の疾患概念は1954年, Johnson'が初めて Leriche syndrome からの中枢側進行性 血栓閉塞例の存在を報告したのが最初である.1960年, Rob ら゙は腎動脈分岐部近くまで中枢側進行した腹部 大動脈血栓閉塞16例を報告し，疾患名を高位大動脈閉
塞症 high aortic occlusion と名付けた. Bergan ら $ら^{3)}$ 本症 Leriche syndrome の上行性血栓閉塞状態である と考之, 傍腎動脈大動脈閉塞症 juxtarenal aortic occlusion と表現している. 本邦でも両者の表現が用 いられているが, 後者の方が解剖学的には具体的であ る.

発症機序としては Leriche syndromeの病態下に run-off 血管として機能していた下腸間膜動脈の急性 血栓閉塞が原因であるとする報告が多い2) 4). 発症頻 度はStarrett ら゙の報告によると33,226例の剖検で腹

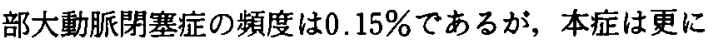
少ない. 本邦では松本らかが下肢閉塞性動脈硬化症の 649例中5.5\%であったと報告している．

慢性高位腹部大動脈閉塞症は下肢, 警部の虚血症状 のみでなく腎臓をはじめ腹部内蔵蔵器への血行の阻害 をきたし腎血管性高血圧, 更には腎不全, 腸管壤死を きたす恐れのある重篤な疾患である゙ 行の有無に拘らず手術の対象となる．術式では血栓内 膜摘除 (thrombo-endoarterectomy)，更には人工血管 を用いての骨盤, 下肢へのバイパス術 (ANA)が行わ れている. Starrett ら4)は手術例40例(血栓内膜摘除の み17例，バイパス術追加23例で中枢側人工血管は端々 吻合）での手術死亡率は10\%であったと報告し，松本 $ら^{\text {s) }}$ は手術例33例のうち小範囲閉塞 9 例には血栓内膜 摘除術のみ施行し, 広範囲閉塞18例に ANA 術, risk factor の多い6 例に腋窝動脈から EXT 術を行ってい る. ANA 術の際の中枢側人工血管吻合について端々 吻合を勧める意見が多い6が手術時間，大動脈遮断時 間，出血量またグラフト閉塞の危惧から端側吻合を勧 める意見”もある。なお，血栓内膜摘除の際，通常，腎 動脈血行遮断を要するが，比較的短時間のため，これ のみでは腎機能障害をきたすことはないとされ $ろ^{677)}$. 自験例でも腎動脈遮断を要した症例での平均遮 断時間は最長 25 分平均10分であり術後腎機能異常をき たさなかった。本疾患では一般にANA 術が推奨され ている゙が，全身疾患である動脈硬化症が起因である ため多くの risk factorのためやむなくEXT術を用 いざるを得ないこともある ${ }^{58)}$. 自験例でも EXT 術を 4 例に用い中枢側進行性血栓閉塞を危惧したが McCullough $ら^{81}$ の報告と同様, 最長 4 年経過例も含め て, 幸い血栓閉塞の中枢側進展を認めていない, run-in および run-off の狭囬部位の有無の判定に有用な術後 安静時総大腿動脈 PI 值帛10)もANA 群との間に差を 認めず, EXT 術でも十分な血行維持が可能であった。 
急性高位腹部大動脈閉塞症はその成因から saddle embolism に代表される塞栓症と血栓症に分類される が, 臨床症状のみでの両者の鑑別は困難である．塞栓 を来しうる心疾患, 脳梗塞, 間欠性跛行の既往有無, 手術での塞栓物の検証などが鑑別点となる ${ }^{111}$ 。手術成 績の倹討では, 慢性例の成績は良好であるが, 急性例 は不良である(12) 14). Webb ら ${ }^{12}$ は本症の急性閉塞10 例を報告し, 死亡 5 例, 下肢切断 1 例と $50 \%$ の高死亡 率であったと報告し, Tapper ら ${ }^{13)}$ は慢性例の死亡率

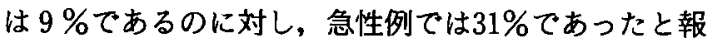
告している. 自験例 2 例も術後 MNMS で失う結果と なった.この様に急性発症例は極めて重篤な病態であ り, 迅速な診断, 蘇生, 発症早期の手術による血行再

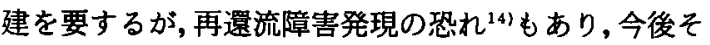
の手術法の選択には症例個々の病態把㨋を行う必要性 がある。

\section{結 語}

急性 2 例を含む高位腹部大動脈閉塞症10例を経験 し, 急性例 1 例を含む 5 例に ANA 術を他の 5 例に EXT術を用いた．急性例は MNMS 発症のため救命 出来なかった。

\section{文献}

1) Johnson JK : Ascending thrombosis of abdominal aorta as fatal complication of Leriche syndrome. Arch Surg 69: 663-668, 1954

2) Rob CG, Downs AR: Chronic occlusive disease of the aorta and iliac arteries (treatment and results). J Cardiovasc Surg 1: 57-64, 1960

3) Bergan JJ, Trippel $\mathrm{OH}$ : Management of juxtarenal aortic occlusion. Arch Surg 87: 230-
238, 1963

4) Starret RW, Stoney RJ : Juxtarenal aortic occlusion. Surgery $76: 890-897,1974$

5）松本興治, 橋本昌紀, 山田 拓他：高位腹部大動脈 閉塞症に対する血行再建術. 外科 $53: 189-195$, 1991

6) Liddicoat JE, Bekassy SM, Dang MH, et al: Complete occlusion of the infrarenal abdominal aorta: Management and results in 64 patients. Surgery $77: 467-472,1975$

7) 江里健輔, 秋本文一：Leriche 症候群. 臨外 45 ： $551-557,1990$

8) McCullough JL, Mackey WC, O'Donnell T, et al : Inftarenal aortic occlusion : A ressessment of surgical indications. Am J Surg 146: 178182,1983

9) Bada HS, Sumner DS : Transcutaneous Doppler ultrasound: Pulsatility index, mean flow velosity, end diastolic flow velocity, and cerebral blood flow. J Pediatr 104 : 395-397, 1984

10) Foley WD, Erickson SJ : Color Doppler flow imaging. AJR 156:3-14, 1991

11）大内 博, 木村道夫, 石井 洋他：急性高位腹部大 動脈閉塞症の手術経験。手術 $37 ： 1287-1290$, 1983

12) Webb KH, Jacocks MA : Acute aortic occlusion. Am J Surg 155 : 405-409, 1988

13) Tapper SS. Jenkins JM, Edwards WH, et al: Juxtarenal aortic occlusion. Ann Surg 215 : 443 $-450,1992$

14）吉田貞夫, 軸屋智昭, 平松祐司他：急性動脈閉塞症 状を呈した高位腹部大動脈閉塞症の 1 手術. 日心 㦹血管外会誌 $22: 433-436,1993$

\title{
TREATMENTS AND PROBLEMS IN CASES OF HIGH AORTIC OCCLUSION
}

\author{
Yoshiki NONAMI, Souichi ASANO, Kouzi SATO, Hideaki NISHIMORI, \\ Takashi FUKUTOMI, Akira YAMAMOTO, Toshiyuki YAMASHIRO \\ and Shohei OGOSHI \\ Department of Surgery II, Kochi Medical School
}

Our experience with 10 cases of high aortic occlusion including 2 cases in an emergency phase during a recent 14-year period (1981-1995) are reviewed. Five cases including 1 case in an emergency phase were operated on in a fasion of anatomical bypass, and other 5 cases including 1 case in an emergency phase in a fasion of extra-anatomical bypass. Two cases in an emergency phase were lost in vain due to myonephropathic metabolic syndrome (MNMS).

We discussed the patient's habitus, pre-operative, post-operative complications, changes in the renal function, operative procedures, and prognosis. Clinical signs seen in the two cases in an emergency phase are also presented. 